\title{
The Effect of Portfolio Assessment Technique on Writing Performance of EFL Learners
}

\author{
Omid Tabatabaei \\ English department, Islamic Azad University, Najafabad Branch, Iran \\ Farzaneh Assefi \\ English department, Islamic Azad University, Najafabad Branch, Iran \\ E-mail: f.assefi@yahoo.com
}

Received: January 10, 2012

Accepted: March 26, 2012

Published: May 1, 2012

doi:10.5539/elt.v5n5p138

URL: http://dx.doi.org/10.5539/elt.v5n5p138

\begin{abstract}
Nowadays, writing has received a great degree of attention not only because it plays a significant role in transforming knowledge and learning but also in fostering creativity and when acquiring of a special language skill is seen as important, its assessment becomes important as well and writing is no exception. This study intended to investigate the effect of portfolio assessment technique as a teaching, learning and assessment tool on writing performance of EFL learners. Writing sub-skills has also been taken into account. To this end, forty Iranian EFL learners who were all English teaching majors were randomly divided into two groups: experimental $(n=20)$ and control $(n=20)$. The experimental group received the treatment i.e. portfolio assessment while the control group underwent the traditional approach of writing assessment. The result of statistical analysis indicated that the students in experimental group outperformed the students in control group in their writing performance and its sub-skills of focus, elaboration, organization, conventions and vocabulary. The findings suggest that portfolio assessment technique improves writing ability of the students. The results have also some implications for assessment, teaching and learning of L2 writing.
\end{abstract}

Keywords: Portfolio assessment technique, Writing performance, Writing sub-skill, EFL learner

\section{Introduction}

Recently, Writing is receiving great interest and a significant role in second and foreign language education but teaching English L2 writing is different from other skills of language since, it is used as a support skill in language learning (Reid, 2002). The method of teaching English writing in language classes have been shifting from traditional way of the end product to the process of creating writing. By such an emphasis on writing process, students learn how to develop their writing, who to solve the problems and how to think critically. However, it is somehow difficult to evaluate this new method of writing via traditional assessment techniques such as timed impromptu writing test. Therefore new ways of assessment have been developed to demonstrate what students learn and what they can do with their own knowledge. These new ways of assessment are called "authentic" or " alternative" measures. Among all the procedures of alternative assessment, portfolio has become a popular technique, currently. Portfolios show students' progress, achievement and self-reflection in one or more areas (Paulson \& Paulson, 1991). Portfolio assessment is an ongoing process. It does no evaluate progress and performance of the learners through an impromptu paper and pencil test or enable instructors evaluating their student's performances within a very short and limited period of time. According to Gosselin (1998) an ongoing assessment is a learning process that examines and document learner progress at a certain intervals. The main goals of portfolio assessment are encouraging learners to become more autonomous, take the control of their learning, make decisions, participate in the evaluation of their own work and solve the problem they may face, individually.

Although students' active participation is vital during the portfolio assessment process, the teacher is the key to the successful use of such strategy (Neimon, 1999). According to Espstein (2005) portfolio assessment transform the role the teacher away from generating comparative rankings of achievement and toward improving student achievement through evaluation feedback and self-reflection.

Despite of its popularity, using writing portfolios is not so common in EFL contexts. At the end of the term, students are commonly given numerical grades for their writing assignment which is a product-oriented approach and may 
not be an appropriate indicator for the student writing ability and teacher may not be able to make a good judgments about their development as writers. Thus, applying portfolio as an alternative assessment technique instead of a traditional impromptu writing test may help teachers to make better judgment about students' writing ability. Accordingly, the purpose of this study is to investigate and explore if portfolio assessment has any positive effect on writing performance of EFL learners.

\section{Literature Review}

\subsection{Origin of Portfolio Assessment}

There has been a paradigm shift from traditional learning settings and evaluating the end product toward the student-centered learning settings and testing learning process and performance during the constructivist post method era. This new change from summative assessment to formative assessment has called "Authentic" or "Alternative" assessment which stresses the need for assessment to be integrated with the goals of the curriculum and to have a constructive relationship with teaching and learning (McNamara, 2000). It includes a variety of assessment procedures such as learner- centered assessment, student designed tests, portfolio assessment and self-assessment that the teacher and students can collaboratively choose and use successfully in language classrooms. Among these, portfolio assessment, as the most effective, interesting and popular alternatives to standardized tests, is widely recognized and used in the domain of teaching and learning of EFL/ESL writing. It is defined as "a purposeful collection of students' work that demonstrates to students others their effort, progress and achievement in given area" (Genesee and Upshur, 1996). It is worth mentioning that portfolio assessment is a kind of portfolios; whereas a portfolio is a collection of collection of a student assignment samples, portfolio assessment is the process of creating, collecting, and evaluating contents of the portfolio (Moya \& O'Malley, 1994).

\subsection{Portfolio Assessment in EFL Writing Context}

Currently, teachers tend to apply a process-oriented technique in writing instruction. In such technique students spend time to select the topics, gather information, write about the topics and before submitting a final piece of writing, draft, revise and edit it. The new trend in teaching writing in EFL classrooms is concentrating on writing processes to create a certain product, therefore, it is essential to apply an assessment technique that develop and encourage such trend as assessment and teaching are two sides of the similar coin. Portfolio assessment, as an authentic innovative technique of assessment provides a tool of assessing the processes of writing as well as the end product of writing. It is a technique to improve students' writing performance. Students are asked to choose their best pieces of writing to put in portfolio to submit assessment. Students can also include those samples of writing that represent the development of writing process, including planning, drafting, revising and editing. Portfolio assessment can develop students' autonomy, critical thinking and linguistic competence. Furthermore, it supports the notion that writing is process that involves growth, development, and learning as well as a product (weiser, 1992).

In the literature of teaching and learning EFL writing, there are a number of studies that discuss about the development of portfolio assessment and the students' attitudes toward using portfolio but it has not been so enlarged by quantitative research to investigate using portfolio with EFL learners. Some experimental studies have been conducted in last decade dealing with portfolio assessment that report technical information and employ accepted research techniques (Herman \& Winters, 1994). In an experimental study, Aly (2002) suggested a writing process approach to improve students' writing skills. The experiment was conducted at the English Department, Faculty of Education, in Shams University. Forty, second year male and female students were randomly assigned to the experimental group. The instruments of the study included a student questionnaire and a pre-post writing composition text. Conferencing was an integral component in the workshop to teaching writing as an attempt to create interaction between the teacher and the student. Findings showed that using writing workshop approach improved the students' writing. It is clear that such approach helped students to have some more sense of responsibility towards group and individual work. Apple and Shimo (2004) tested students' perceptions of portfolio creation in an EFL context in Japan. The participants were sixty one students in two different universities attending English writing class. A student-selected portfolio work was used as the elementary means of assessment. Tests were not used for assessment. A self-report questionnaire was used to measure the responses of the learners which showed that they firmly believed that portfolio technique helped them improve expressive and compositional writing ability. Marefat (2004) investigated views of the students on portfolio use in an email-based EFL writing class. The majority of the subjects found that the portfolio technique was a positive opportunity for their writing. In addition, some students improved a personal understanding of their learning process. Hirvela and Sweetland (2005) described two case studies which investigated student experiences with portfolios in two ESL writing classes. The findings showed that the subjects liked the idea of portfolios but they did not endorse their use as employed in those writing courses. Paesani (2006) conducted a writing portfolio project whose purpose was to assemble the learning of skills, content 
and language competences through literary study. The reactions of the students to the portfolio writing project stressed the perceived value of the project in promoting the development of the students' writing skills and grammatical competence.

\section{Statement of the Problem}

Learning to be a proficient writer in a second language and especially foreign language is a difficult task for most learners, as they must face a complex set of challenges that include mastering lots of lexical, grammatical, and syntactic skills. After the paradigm shift from traditional way of writing assessment to alternative form of writing assessment, portfolio assessment technique has received a great degree of attention as a perfect pedagogical tool for non-native English students that can closely tie assessment, teaching and learning all together. Although, it has potential benefits to students, it does not apply in Iranian educational setting and timed impromptu writing test with its all shortcomings, still dominate in EFL writing classes which cannot be a good indicator of students' progress and teacher instruction. Therefore, this study is an attempt to explore whether the application of portfolio assessment technique as a process-oriented writing pedagogy improves EFL learners' writing ability and the writing sub-skills of focus, elaboration, organization, conventions, and vocabulary.

\section{Objectives of the Study}

This study is an attempt to investigate the effect of applying portfolio assessment technique on improving the writing performance of EFL learners and how they can develop as writers by emphasizing on written reflection, process, collaboration, multiple drafting, and functional writing. It considers the assessment process as one of the most important element of curriculum. Furthermore, the current study tries to modify the way assessment process is looked at as an end in itself, whereas it should be seen as a significant and integral part of teaching. As instruction and assessment are linked, portfolio assessment technique can be applied for instructional goals in EFL educational setting. So this study tries to find out whether it is feasible to use it in the teaching writing in academic EFL setting.

\section{Research Questions}

Based on the above mentioned problem, the researcher attempts to answer the following questions:

1. Does the application of portfolio assessment technique have any significant positive effect on writing performance of EFL learners?

2. Does the application of portfolio assessment technique affect EFL learners' writing ability in terms of focus, elaboration, organization, conventions, and vocabulary?

\section{Research Hypotheses}

H01. The application of portfolio assessment strategy has no significant positive effect on the writing performance of EFL learners.

H02. The application of portfolio assessment strategy has no significant positive effect on EFL learners' writing sub-skills.

\section{Methodology}

\subsection{Participants}

Forty Iranian EFL learners who were all English teaching majors formed the whole population of this study. A proficiency test of TOEFL was administered to the learners since the subjects of this study were supposed to be at the upper-intermediate level of English proficiency. Afterwards a standard test of writing taken from Cambridge IELTS 5 (Cambridge university press) was administered to ensure about the homogeneity of the subjects regarding their writing ability. Then they were randomly divided into two groups of 20: experimental group $(n=20)$ and control group $(\mathrm{n}=20)$.

\subsection{Instruments}

\subsubsection{TOEFL Test}

First of all, in order to ensure the homogeneity of the subjects regarding language proficiency, a TOEFL test adopted from Barons (2001) was administered to them. The test consisted of three parts; part 1: grammar (15 items), part two: error identifications ( 25 items), and part3: reading comprehension (23 items), which was totally 6 items. 1 point for each item (the total raw score $=63$ for each participant)

\subsubsection{Standardized Writing Test - IELTS}

After administering the TOEFL test to the participants, a standardized writing test-IELTS- was administered in order to screen the participants regarding their writing ability. The test takers were provided with this topic: 'advantage and 
disadvantages of city life and country life'. Since this study aimed at investigating the effect of an assessment technique (portfolio assessment) on L2 learners 'achievement in writing, they needed to be homogenized in terms of writing ability. Then, all the compositions were scored by three competent raters according to the adopted version of rating scale (Wang \& Liao, 2008). Rating was done on for the five criteria of focus, elaboration, organization, convention, and vocabulary. Each participants' composition score was the mean of the three raters' scores (the total score $=100)$. Finally, the Pearson correlation coefficient ascertained that suitable levels of inter-rater reliability were achieved.

\subsubsection{Portfolio Assessment Model}

The portfolio assessment model used in this study is based on the "classroom portfolio model" and consisted of three procedures: collection, selection and reflection, as suggested by Hamp-Lyons and Condon (2000). (See Figure 1)

\subsubsection{Analytic Scoring Rubric}

The writing scoring rubric utilized in this study consisted of five subscales: focus, elaboration, organization, convention and vocabulary, each with five levels. It is a modified version of Wang and Liao's (2008). (See Appendix A)

\section{Procedure}

A group of forty male and female EFL learners who were studying at upper-intermediate level of English language proficiency in an English language institute was given a TOEFL test in order to be homogenized. Then a standardized writing test -IELTS- was administered to ensure the homogeneity of the subjects regarding their writing ability. Next, they were randomly divided into two groups, experimental and control. In this study, the application of portfolio assessment technique was the independent variable and The writing performance and writing sub-skills which were measured through a writing scoring rubric modified from Wang and Liao (2008) were the dependent variables. The portfolio model applied in this study was the "classroom model of portfolio" and the portfolio procedure consisted of collection, selection, reflection as suggested by Hamp-Lyons \& Condon (2000). At the beginning of the term, the instructor explains about the design, goal and procedure of the portfolio assessment. The students wrote about the different topics by receiving the first students' writing drafts the instructor (the researcher) read them carefully and patiently. After that she wrote her notes and comments according to the writing scoring rubric and those five criteria: focus, elaboration, organization, conventions and vocabulary. By means of these comments, learners could gain their strong and weak points in these aspects of their writing. Then, the learners were asked to reflect on or self-assess their writing and evaluate it. As peer collaboration, they were also asked to review their partner's written tasks. In addition, after the class, the learners consulted their instructor to obtain comments in one-to-one conference. Then, they revised and redrafted their writing upon their instructor's and peer's feedbacks and own reflections. The control group received traditional assessment of writing. The teacher clearly explained about different parts: developing topic sentence, body paragraphs, conclusion, etc. the students were asked to write about different topics which were in their textbook or they were interested in. Unlike the experimental group they were not asked to reflect on their writing. Their writing ability was evaluated based on the final exam. At the end of the term, the students in experimental group were asked to choose three out of five of their best writings for final evaluation. Like in Lam and Lee's (2008) study, the portfolio score of the students was the average of scores on those three final drafts. Evaluating the students' portfolio was based on analytic rubric modified from Lam and Lee (2010) which consists of five subscales of focus, elaboration, organization, convention, and vocabulary, each with five levels. Each participant's score was the mean of the three raters' scores (the total score=100). This rubric was also used to rate students' writing for both pre-test and post-test.

\section{Results}

The purpose of the first research question was to find out whether the application of portfolio assessment technique has any significant positive effect on the writing performance of EFL learners. To address this question, descriptive statistics of participants' performance on writing post-test is presented in table 1. The two sets of compositions written by portfolio (experimental) and control groups were also compared using an independent sample t-test (table 2).

According to table 1, there is a slight difference between the mean scores of the control group and portfolio groups, which are 72.45 and 71.15 respectively. In order to see whether their performance is statistically significant, Table 2 represents the inferential statistics of the results of the writing post-test running on the scores.

The table 2 indicates that there are statistically significant differences between the mean scores of the portfolio and control groups at $\mathrm{p}<.05$. The mean scores of portfolio group are higher than that of control group. This means that portfolio group outperformed the control group in writing. So, the first null hypothesis which stated that the 
application of portfolio assessment technique has no significant positive effect on writing performance of EFL learners was rejected. In response to the second research question, Table 3 presents data collected to determine if there are significant differences between the means of scores of the experimental and control groups on each of the writing sub-skills after the treatment. To be able to statistically reject or accept the null hypothesis, an independent samples t-test was also run (table 4).

As Table 3 shows, the mean scores of the sub-skills of the writing skills: focus, elaboration, organization, convention, and vocabulary for control group are 14.25, 14.50, 13.85, 14.45, and 13.70 respectively. The mean of the same sub-skills for the portfolio group are 15.70, 15.40, 14.80, 16.00 and 14.90 respectively. By comparing the means of the two groups, as shown in the above table, it can be inferred that there are statistically significant differences between two groups in each of the five writing sub-skills. The data in table 5 indicate that the students in portfolio group showed improvement in each of the writing sub-skills especially in the sub-skill of conventions. They have higher mean scores than control group which are 16.00 and 14.45 respectively. Table 4 presents the results of independent samples t-test on the writing post-test sub-skill scores.

According to Table 4 the inferential statistics also confirm the descriptive findings mentioned previously. As this table uncovers, the differences between the participants' performance in both groups on the sub-skills of focus $\mathrm{t}$ $(38)=-2.162, \mathrm{p}=.037)$, elaboration $\mathrm{t}(38)=--2.392, \mathrm{p}=.022)$, organization $\mathrm{t}(38)=-2.156, \mathrm{p}=.037)$, convention $\mathrm{t}(38)$ $=-3.639, \mathrm{p}=.001$ ), and vocabulary $\mathrm{t}(38)=-2.583, \mathrm{p}=.014$ was statistically significant, meaning that the achievement of students in focus, elaboration, organization, convention and vocabulary did vary according to the type of assessment, traditional impromptu versus portfolio. Therefore, the second null hypothesis which stated that the application of portfolio assessment has no significant positive effect on writing sub-skills was also rejected.

\section{Discussion}

The results of quantitative data analysis showed that portfolio assessment had a positive significant effect on students' overall writing. It shows that the combination of the portfolio scores and the writing test scores to assess the subjects' writing performance and growth can be beneficial. This method is consistent with what Moya and O'Malley (1994) have suggested that a single measure is incapable of estimating the variety of skills, processes, knowledge and strategies that combine to determine student progress. The results echo earlier findings in the literature. Regarding the first research question, this study found that portfolio assessment significantly improves students' writing performance in general. This is in line with the findings of earlier research conducted by Yurdabakan and Erdogan's (2009), that investigated the portfolio assessment on reading, listening and writing skills of a group of secondary school students in Turkey. Overall, the results indicated that portfolio assessment had a significant positive effect on students' writing skills. The mean score of writing in the portfolio assessment group was significantly higher than that in the control group. Thus, this finding confirms the results of the current study as well. The research findings are also in congruity with the study of Elahinia (2004): She investigated the effect of portfolio assessment on Iranian EFL learner's writing achievement. She dfound that portfolio assessment had a significant positive effect on writing performance of the subjects. The students in experimental group (i.e. Portfolio Assessment group) outperformed those in control group on writing test given at the end of the experiment. So, the findings are also in line with this study, too. The results are also consistent with Fahed Al-Serhani's (2007) findings that portfolio Assessment technique significantly improves students' writing in general and writing sub-skills in particular.

Concerning the second research question, this study found that portfolio assessment has a significant positive effect on EFL learners' writing sub-skills. The students in experimental group showed a satisfactory improvement with reference to each of the writing sub-skills i.e., focus, elaboration, organization, conventions, and vocabulary. The results of this study is completely in line with the study of Krigere and Sardeiko (2000) which indicated that portfolio assessments were an effective tool for developing language skills in general and writing skills in particular. This results are in agreement with the study of Aly (2000) that the students in experimental group could realize their weak points (skills) in writing and develop as writers and Khalil (2002, pp.667-668) who found that portfolio assessment helped the students to increase their ability to learn and improve writing skills. Writing portfolios can be useful in EFL classes as a perfect technique for teaching, learning, and assessment. They also suggest authentic information about students' progress and help them to promote their writing ability in general and its sub-skills in particular. As the limitation, it can be claimed that age, gender, affective factors and background knowledge can moderate the effect of portfolio assessment technique on writing and its sub-skills and they are left untouched in the current study. So, further studies require in EFL context to investigate in these areas.

\section{Conclusion}

Based on the findings of the current study, portfolio assessment technique has a significant positive effect on EFL 
learners' overall writing ability and the sub-skills of focus, elaboration, organization and vocabulary. It is an effective instructional technique as well as assessment tool and can provide evidence of knowledge, dispositions, and skills. In addition, portfolio assessment can offer authentic information about the progress of students and can be used as a means of helping students to overcome their writing anxiety in L2. A positive correlation appeared in the portfolio in relation to the English Writing Test. Using portfolio assessment technique allowed students to create a bridge between their teacher and themselves. The teacher can use portfolio assessment technique to analyze student growth and use the information for decision making regarding future instruction. It was also concluded that portfolio can be used as a teaching technique in writing classes to improve students' writing ability. It can be used to encourage and motivate weak writers.

In sum, this study suggested the formative potential of portfolio assessment to help students to boost their English writing ability. They were actively involved in learning and assessment in the portfolio assessment program. The students in portfolio group revisited, reflected on and revised their writing during the course and put their final drafts in their portfolios.

This study highlights important implications. First, portfolio assessment technique is a promising authentic assessment technique for EFL writing classes. Through proper application, portfolio assessment technique has the potential to increase instructor professionalism through active and meaningful involvement in student assessment. It can be a perfect assessment tool as well as instructional instrument in EFL educational setting.

There are several limitations to this study. The first and the foremost is that this study conducted in an English language institute in a small scale and gave a positive feedback but these results may not be cited as general and authentic criteria to follow portfolio assessment technique in EFL settings. We have to acknowledge the very fact that writing problems among EFL learners are the past carriers which they carry forward from their secondary schools and this may vary from one EFL situation to the other. So, further studies require investigating the effect of portfolio assessment technique on writing in different EFL contexts. Second, Gender, age and affective factors are left untouched in this study and further research needs to see if they can moderate the impact of portfolio assessment on writing and its sub-skills. Finally, the present study didn't investigate how students' attitudes toward portfolio assessment technique and their beliefs about writing can shape their involvement with the writing process during this portfolio program.

\section{References}

Aly, M. M. (2002, April). The effect of using the writing workshop approach on developing students teachers composing skills. Proceedings of the 21th CDELT National Symposium on English Language Teaching: Meeting Challenges of ELT in the Arab World, Ain Shams University, Cairo, 131-169.

Aly, M. M. (2000, December). Portfolio assessment: helping EFL students develop as writers. Studies in Curriculum \& Instruction, 62, 232-69.

Apple, M., \& Shimo, E. (2004). Learners to teacher: portfolios, please! Perceptions of portfolio assessment in EFL classroom. Proceedings of JALT pan-SIG Conference. Tokyo Keizai University, 53-58. Portfolio Assessment \& Writing Performance 119.

Barootchi, N., \& Keshavarz, M. H. (2002). Assessment of achievement through portfolios and teacher-made tests. Educational Research, 44(3), 279-288.

Elahinia, H. (2004). Assessment of writing through portfolios and achievement tests. Unpublished M.A thesis, Teacher Training University, Iran.

Epstein, A. (2005). Introduction to portfolios. Retrieved June 5, 2011, from Pearson Education, INC. Web Site: $\mathrm{http} / / \mathrm{www} \cdot$ teachervision.fen.Com/page/4528.html?Detoured=1

Fahed Al-Serhani, W. (2007). The effect of portfolio assessment on the writing performance of EFL secondary school students in Saudi Arabia. Unpublished M.A thesis, Taibah University, Saudi Arabia.

Genesee, E., \& Upshur, J. (1996). Classroom-based evaluation in second language education. New York: Cambridge University Press.

Ghoorchaei, Tavakoli, \& Ansari. (2010). The Impact of Portfolio Assessment On Iranian EFL Students' Essay Writing: A Process-Oriented Approach. GEMA Online TM Journal of Language Studies, 35, Volume 10(3), 2010.

Gosselin, Linda A. (1998). "Is Ongoing Assessment Fully Learner-Centered?" Adventures in Assessment, Vol. 11, winter 1998.

Hamp-Lyons, L., \& Condon, W. (2000). Assessing the portfolio: Principles for practice, theory, and research. 
Cresskill: Hampton Press.

Herman, J. L., \& Winters, L. (1994). Portfolio research: A slim collection. Educational Leadership, 52, 48-55.

Hirvela, A., \& Sweetland, Y. L. (2005). Two case studies of L2 writers' experiences across learning-directed portfolio contexts. Assessing Writing, 10(3), 192-213. http://dx.doi.org/10.1016/j.asw.2005.07.001

Krigere, G., \& Sardiko, L. (2002). Portfolio assessment in a young learners' classroom. Retrieved April 27, 2011, from Latvian Association of Language Teaching Web Site: http: //www.1.vasa.1v/portfolio.php

Lam, R., \& Lee, I. (2010). Balancing the dual functions of portfolio assessment. ELT Journal, 64(1), 54-64.

Marefat, F. (2004). Portfolio revisited. Iranian Journal of Applied Linguistics, 7(2), 79. http://dx.doi.org/10.1093/elt/ccp024

Moya, S., \& O'Malley, J. M. (1994, Spring). A portfolio assessment model for ESL. The Journal of Educational Issues of Language Minority Students, 13, 13-36.

McNamara, T. (2000). Language testing. In H. G. Widdowson (Series Ed.), Oxford Introductions to Language Study. Oxford: Oxford University Press.

Neiman, L. V. (1999). Linking theory and practice in portfolio assessment. Retrieved March 24, 2011, from On WEAC Web Site: http: //www. weac

Paesani, K. (2006). Exercises de style: Developing multiple competencies writing portfolio. Foreign Language Annals, 39(4), 618-39. http://dx.doi.org/10.1111/j.1944-9720.2006.tb02280.x

Paulson, F. L., Paulson, P. R., \& Meyer, C A. (1991, February). What make a portfolio Educational Leadership, 48(1), 60-63.

Reid, J. (2002). Writing. In R. Carter, \& D. Nunan (Eds.), The Cambridge guide to teaching English to speakers of other languages (4th ed., pp. 28-33). Cambridge: Cambridge University Press.

Wang, Y. H., \& Liao, H. C. (2008). The application of learning portfolio assessment for students in the technological and vocational education system. Asian EFL Journal, 10(2), 132-154.

Weiser, I. (1992). Portfolio practice and assessment for collegiate basic writers. In K. B. Yancey (Ed.), Portfolios in the writing classroom: An introduction (pp.89-101). Urbana, IL: National Council of Teachers of English.

Yurdabakan, I., \& Erdogan, T. (2009). The effects of portfolio assessment on reading, listening and writing skills of secondary school prep class students. The Journal of International Social Research, 2(9), 526-538.

\section{Appendix A: Tables}

Table1. Descriptive statistics of participants' performance on writing post test

Group Statistics

\begin{tabular}{|cc|c|c|c|c|}
\hline & group & $\mathrm{N}$ & Mean & Std. Deviation & Std. Error Mean \\
\hline \multirow{2}{*}{ posttest } & control & 20 & 72.45 & 3.546 & .793 \\
& portfolio & 20 & 74.85 & 3.631 & .812 \\
\hline
\end{tabular}

Table 2. Independent samples test

Independent Samples Test

\begin{tabular}{|cc|c|c|c|c|c|}
\hline \multirow{2}{*}{} & \multicolumn{2}{|c|}{$\begin{array}{c}\text { Levene's Test for } \\
\text { Equality of variance }\end{array}$} & \multicolumn{2}{|c|}{ t-test for Equality of Means } \\
\cline { 3 - 7 } & $\mathrm{F}$ & Sig. & $\mathrm{t}$ & $\mathrm{df}$ & Sig. (2-tailed) \\
\hline Posttest & $\begin{array}{c}\text { Equal variances } \\
\text { assumed } \\
\text { Equal variances } \\
\text { not assumed }\end{array}$ & .001 & .972 & -2.115 & 38 & .041 \\
\hline
\end{tabular}


Table 3. Descriptive Statistics of Participants Performance on the Sub-skills of Writing Post-test

Group Statistics

\begin{tabular}{|cc|c|c|c|c|}
\hline skills & Groups & & & & \\
& & $\mathrm{N}$ & Mean & Std. Deviation & Std. Error Mean \\
\hline \multirow{2}{*}{ focus } & control & 20 & 14.85 & 1.309 & .293 \\
& portfolio & 20 & 15.70 & 1.174 & .263 \\
\hline \multirow{2}{*}{ elaboration } & control & 20 & 14.50 & 1.318 & .295 \\
& portfolio & 20 & 15.40 & 1.046 & .234 \\
\hline \multirow{2}{*}{ organization } & control & 20 & 13.85 & 1.268 & .284 \\
& portfolio & 20 & 14.80 & 1.508 & .337 \\
\hline \multirow{2}{*}{ conventions } & control & 20 & 14.45 & 1.356 & .303 \\
& portfolio & 20 & 16.00 & 1.338 & .299 \\
\hline \multirow{2}{*}{ vocabulary } & control & 20 & 13.70 & 1.593 & .356 \\
& portfolio & 20 & 14.90 & 1.334 & .298 \\
\hline
\end{tabular}

Table 4. The Results of the t-test for the Sub-skills of Writing Post-test

Independent Samples Test

\begin{tabular}{|c|c|c|c|c|c|c|}
\hline & & \multicolumn{2}{|c|}{$\begin{array}{c}\text { Levene's Test for } \\
\text { Equality of } \\
\text { Variances }\end{array}$} & \multicolumn{3}{|c|}{ t-test for Equality of Means } \\
\hline & & $\mathrm{F}$ & Sig. & $\mathrm{t}$ & df & $\begin{array}{c}\text { Sig. } \\
\text { (2-tailed) }\end{array}$ \\
\hline Focus & $\begin{array}{l}\text { Equal variances assumed } \\
\text { Equal variances not } \\
\text { assumed }\end{array}$ & 018 & .893 & $\begin{array}{l}-2.162 \\
-2.162\end{array}$ & $\begin{array}{c}38 \\
37.561\end{array}$ & $\begin{array}{l}.037 \\
.037\end{array}$ \\
\hline Elaboration & $\begin{array}{c}\text { Equal variances assumed } \\
\text { Equal variances not } \\
\text { assumed }\end{array}$ & .950 & 336. & $\begin{array}{l}-2.392 \\
-2.392 \\
\end{array}$ & $\begin{array}{c}38 \\
36.742 \\
\end{array}$ & .022 \\
\hline Organization & $\begin{array}{c}\text { Equal variances assumed } \\
\text { Equal variances not } \\
\text { assumed }\end{array}$ & 1.952 & .110 & $\begin{array}{l}-2.156 \\
-2.156\end{array}$ & $\begin{array}{c}38 \\
36.974\end{array}$ & $\begin{array}{l}.037 \\
.038\end{array}$ \\
\hline Convention & $\begin{array}{c}\text { Equal variances assumed } \\
\text { Equal variances not } \\
\text { assumed }\end{array}$ & .324 & .572 & $\begin{array}{l}-3.639 \\
-3.639\end{array}$ & $\begin{array}{c}38 \\
37.993\end{array}$ & $\begin{array}{l}.001 \\
.001\end{array}$ \\
\hline Vocabulary & $\begin{array}{l}\text { Equal variances assumed } \\
\text { Equal variances not } \\
\text { assumed }\end{array}$ & .044 & .834 & $\begin{array}{l}-2.583 \\
-2.583\end{array}$ & $\begin{array}{c}38 \\
38.863\end{array}$ & $\begin{array}{l}.014 \\
.014\end{array}$ \\
\hline
\end{tabular}


Appendix B: Writing Scoring Rubric Modified from Wang and Liao (2008)

\begin{tabular}{|c|c|c|}
\hline criteria & descriptors & scores \\
\hline Focus & $\begin{array}{l}\text { 1. Having problems with focus or failing to address the writing task. } \\
\text { 2. Inadequately addressing the writing task. } \\
\text { 3. Addressing the writing task adequately but Sometimes straying from the task. } \\
\text { 4, Addressing most of the writing task. } \\
\text { 5. Specifically addressing the writing task }\end{array}$ & $\begin{array}{l}3 \\
4 \\
5\end{array}$ \\
\hline Organization & $\begin{array}{l}\text { 1. The logical flow of ideas is not clear and connected. } \\
\text { 2. The logical flow of ideas is less clear and connected. } \\
\text { 3. The logical flow of ideas is mostly clear and connected. } \\
\text { 4. The logical flow of ideas is generally clear and connected. } \\
\text { 5. The logical flow of ideas is specifically clear and connected. }\end{array}$ & $\begin{array}{l}1 \\
2 \\
3 \\
4 \\
5 \\
5\end{array}$ \\
\hline Conventions & $\begin{array}{l}\text { 1. Standard English conventions (spelling, grammar and punctuation) are poor } \\
\text { with frequent errors. } \\
\text { 2. Standard English conventions (spelling, grammar and punctuation) are } \\
\text { inappropriate with obvious errors. } \\
\text { 3. Standard English conventions (spelling, grammar and punctuation) are fair } \\
\text { with some minor errors. } \\
\text { 4. Standard English conventions (spelling, grammar and punctuation) are almost } \\
\text { accurate. } \\
\text { 5. Standard English conventions (spelling, grammar and punctuation) are perfect } \\
\text { or near perfect. }\end{array}$ & 4 \\
\hline Vocabulary & $\begin{array}{l}\text { 1. Little knowledge of English vocabulary, idioms and verb forms. } \\
\text { 2. Frequent errors of word/idiom form, choice, usage. Meaning confused or } \\
\text { obscured. } \\
\text { 3. Occasional errors of word/idiom form, choice, usage but meaning not } \\
\text { obscured. } \\
\text { 4. Almost effective word/idiom form, choice, usage. Almost appropriate register. } \\
\text { 5. Effective word/idiom form, choice, usage. Appropriate register. }\end{array}$ & $\begin{array}{l}1 \\
2 \\
3 \\
4\end{array}$ \\
\hline
\end{tabular}




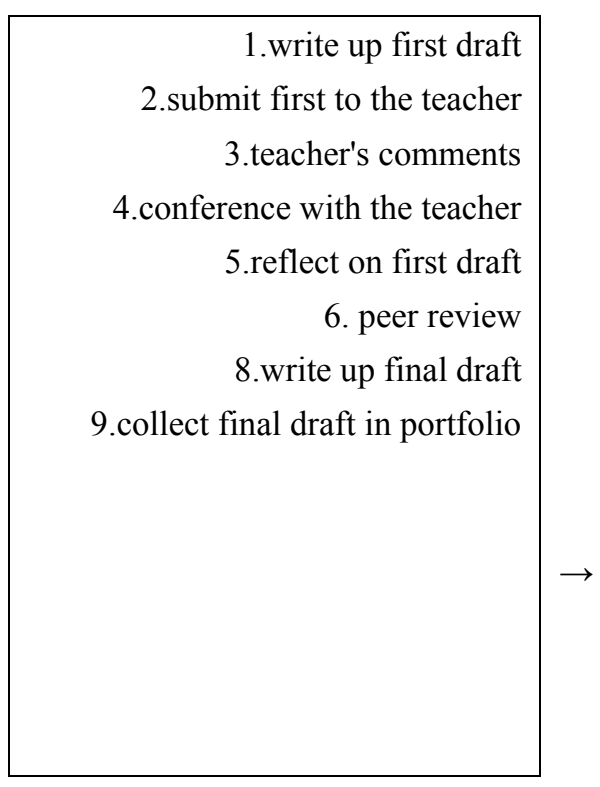

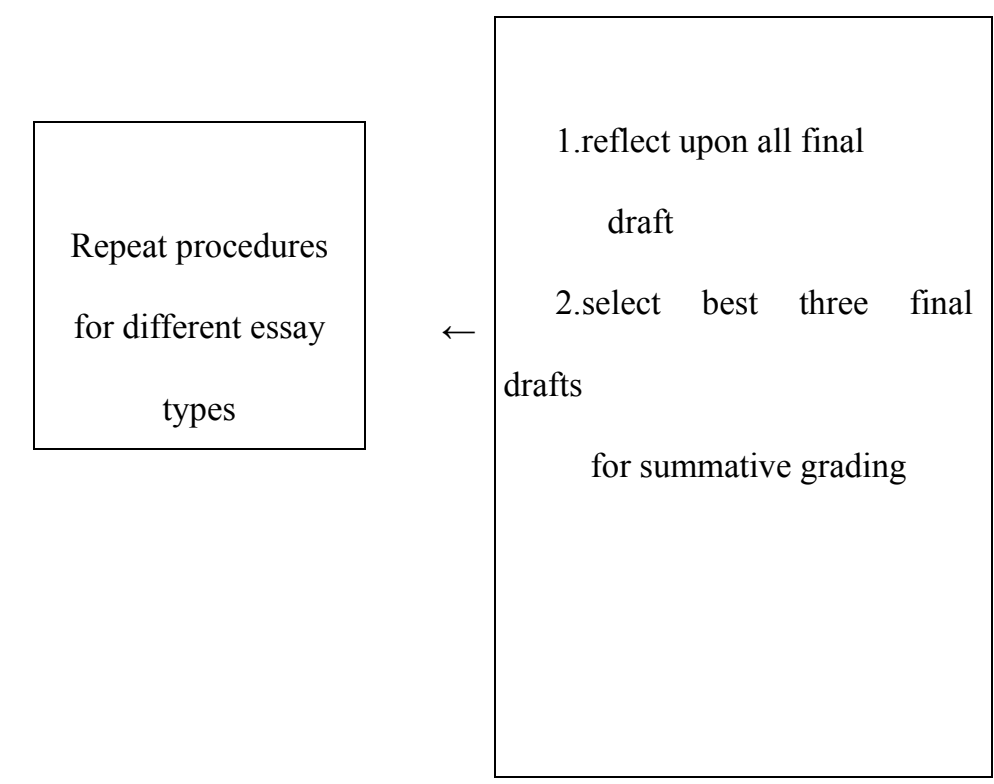

Figure 1. 